\title{
Potentiation of apple procyanidin-triggered apoptosis by the polyamine oxidase inactivator MDL 72527 in human colon cancer-derived metastatic cells
}

\author{
FRANCINE GOSSÉ ${ }^{1}$, STAMATIKI ROUSSI ${ }^{1}$, SYLVAIN GUYOT ${ }^{2}$, ANGÈLE SCHOENFELDER ${ }^{3}$, \\ ANDRÉ MANN $^{3}$, JEAN-PIERRE BERGERAT ${ }^{1}$, NIKOLAUS SEILER ${ }^{1}$ and FRANCIS RAUL ${ }^{1}$ \\ ${ }^{1}$ Université Louis-Pasteur EA3430, Faculty of Medicine; INSERM U682, Laboratory of \\ Nutritional Cancer Prevention, IRCAD, Strasbourg; ${ }^{2}$ INRA, Unité de recherches Cidricoles, Le Rheu; \\ ${ }^{3}$ CNRS-ULP UMR7081, Faculty of Pharmacy, Laboratory of Molecular Pharmacochemistry, Illkirch, France
}

Received March 3, 2006; Accepted April 26, 2006

\begin{abstract}
Apple procyanidins have chemopreventive properties in a model of colon cancer, they affect intracellular signalling pathways, and trigger apoptosis in a human adenocarcinoma-derived metastatic cell line (SW620). In the present study we investigated relationships between procyanidin-induced alterations in polyamine metabolism and apoptotic effects. Apple procyanidins diminish the activities of ornithine decarboxylase and S-adenosyl-Lmethionine decarboxylase, key enzymes of polyamine biosynthesis, and they induce spermidine/spermine $\mathrm{N}^{1}$ acetyltransferase, which initiates retroconversion of polyamines. As a consequence of the enzymatic changes polyamine concentrations are diminished, and $\mathrm{N}^{1}$-acetyl-polyamines accumulate in SW620 cells. In contrast with expectations MDL 72527, an inactivator of polyamine oxidase (PAO), improved the anti-proliferative effect of procyanidins, and caused an increase of the proportion of apoptotic cells, although it prevented the formation of hydrogen peroxide and 3-acetamidopropanal, the cytotoxic products of PAOcatalysed degradation of $\mathrm{N}^{1}$-acetylspermidine and $\mathrm{N}^{1}$ acetylspermine. Addition of $500 \mu \mathrm{M} \mathrm{N}^{1}$-acetylspermidine to the culture medium in the presence of procyanidins mimicked the effect of MDL 72527. Therefore we presume that the enhanced procyanidin-triggered apoptosis by MDL 72527 is mediated by the accumulation of $\mathrm{N}^{1}$-acetyl-polyamines. The observation that apple procyanidins enhance polyamine catabolism and reduce polyamine biosynthesis activity similar to known inducers of SSAT, without sharing their toxicity, and the potentiation of these effects by low concentrations of MDL 72527 suggests apple procyanidins for chemopreventive and therapeutic interventions.
\end{abstract}

Correspondence to: Dr Francis Raul, IRCAD, 1 place de l'hôpital, BP 426, 67091 Strasbourg cedex, France

E-mail: francis.raul@ircad.u-strasbg.fr

Key words: SW620 cells, cell cycle, oxidative stress, polyamines

\section{Introduction}

Apples contain several classes of polyphenols such as flavonoid monomers and condensed tannins, the procyanidins (1). The polyphenol content of apples varies from one variety to another, but procyanidins are predominant (2). They consist mainly of condensed (-)-epicatechin units with a small proportion of $(+)$-catechin. Polyphenolic compounds are known to affect processes that are important for cancer development. Thus, they have antioxidant and radical scavenging properties, and they may prevent carcinogenesis by affecting molecular events in the initiation, promotion and progression stages (3). We have recently reported (4) that apple procyanidins inhibit the growth of human metastatic colon carcinoma-derived SW620 cells. They alter intracellular signalling pathways and induce apoptosis. The apoptotic effects were associated with a $50 \%$ reduction of protein kinase C (PKC) activity (4). Interrelations between PKC activity and polyamine metabolism have repeatedly been found. It was reported for instance that PKC inactivation inhibits the induction of ornithine decarboxylase (ODC), a key enzyme of polyamine biosynthesis (5). Transgenic mice overexpressing PKC show a 3- to 4-fold higher expression of phorbol ester-induced epidermal ODC, when compared with normal littermates (6).

The effect of procyanidins on polyamine metabolism has so far not been studied. The intracellular polyamine content and the activities of key enzymes of polyamine biosynthesis, ODC and S-adenosyl-L-methionine decarboxylase (AdoMetDC), are increased in colonic tumours in comparison with the surrounding tissue (7), and have been considered as logical targets in cancer chemoprevention and therapy $(8,9)$. More recently polyamines have been implicated in cell death programs (10).

Biosynthetic and catabolic reactions of polyamine interconversion are illustrated in Fig. 1. It appears that polyamines are ambivalent regulators of cell functions, promoting cell proliferation or cell death, depending on the cell type, their concentration, and the environmental signals (10-12). Since procyanidins perturbate signal transduction pathways, it could be expected that they affect also polyamine metabolism. In 


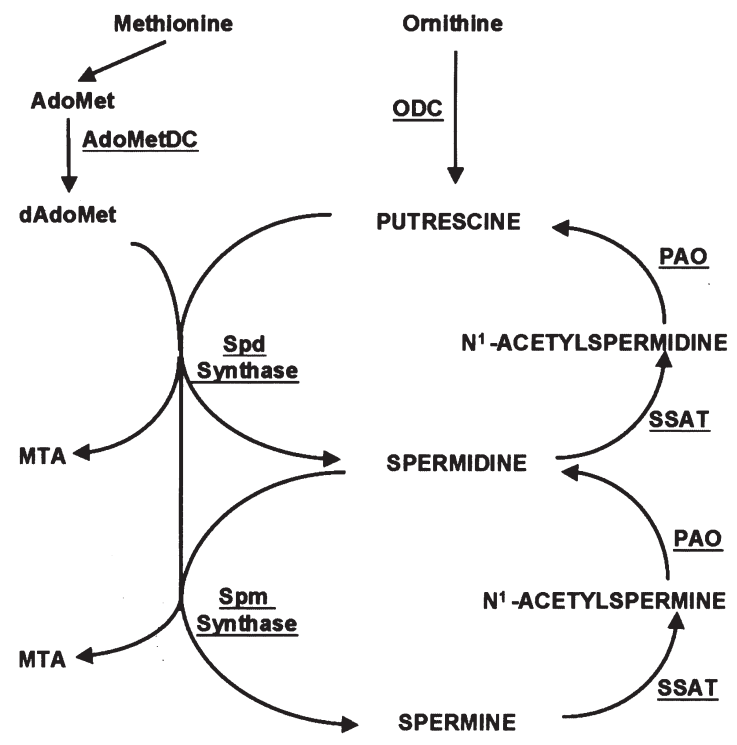

Figure 1. Polyamine interconversion pathway. Rate-limiting of the biosynthetic branch is the formation of dAdoMet and acetylation of spermine and spermidine by SSAT in the catabolic branch. In addition to the general interconversion reactions, oxidative deaminations are involved in the terminal elimination of polyamines (not shown). Acetylated polyamines are also excreted by cells. AdoMetDC, S-adenosylmethionine decarboxylase; AdoMet, S-adenosylmethionine; dAdoMet, decarboxylation product of AdoMet; MTA, methylthioadenosine; ODC, ornithine decarboxylase; PAO, polyamine oxidase; Spd, spermidine; Spm, spermine; SSAT, spermine/ spermidine $\mathrm{N}^{1}$-acetyltransferase

the present study, we investigated, therefore, interrelations between procyanidins and polyamine metabolism of SW620 colon adenocarcinoma-derived metastatic cells. Our data show a previously unknown ability of procyanidins to activate polyamine acetylation and to down-regulate simultaneously polyamine biosynthesis. By using the PAO inactivator MDL 72527 at $50 \mu \mathrm{M}$, a dose which inactivates PAO, but does not inhibit cell growth (13), we demonstrate that the apoptotic effect of procyanidins is unrelated to the formation of reactive oxygen species (ROS), which are generated by enhanced oxidation of polyamines, and that MDL 72527 potentiates the procyanidin-triggered apoptosis. These effects seem to be correlated with the increased formation of $\mathrm{N}^{1}$-acetyl derivatives of spermidine and spermine.

\section{Materials and methods}

Isolation and characterization of apple procyanidins. Polyphenols were purified from a cider apple (Malus domestica, variety Antoinette). Apples were reduced to a homogeneous powder which was extracted by water:ethanol:acetic acid (975:1000:25). After filtration, evaporation under vacuum and freeze drying, the crude extract was dissolved in $2.5 \%$ acetic acid and separated by preparative HPLC (Lichrospher RP 18, $12 \mu \mathrm{m}$, Merck, Darmstadt, Germany) to remove sugars and other non-phenolic polar compounds. Polyphenols were eluted with acetonitrile:water:acetic acid (300:700:25). The fractions containing polyphenols were evaporated and freezedried.

The polyphenols were fractionated on a Fractogel column by a method adapted from Souquet et al (14). Procyanidins were characterized and quantified by thiolysis coupled with reverse-phase HPLC and diode array UV-visible detection (15). On a weight basis, the procyanidin fraction contained $78.4 \%$ procyanidins, consisting of $95 \%$ (-)epicatechin and $4 \%(+)$ catechin. The mean degree of polymerization was close to four. The procyanidin fraction was almost totally devoid of monomeric catechins and other phenols $(<2 \%)$.

Cell culture and treatments. SW620 cells are rapidly growing metastatic cells. They were chosen for this work because we have extensive experience on the polyamine metabolism and effects of the PAO inactivator MDL 72527 on this cell line $(16,17)$. They were obtained from the European Collection of Animal Cell Culture (Salisbury, UK). Cells were seeded at $3 \times 10^{3}$ cells per well in 96-well culture clusters or at $1 \times 10^{6}$ cells in culture dishes (100-mm diameter). They were cultured in modified Eagle's medium (containing $25 \mathrm{mM}$ glucose, glutamax) and supplemented with $3 \%$ heat-inactivated $\left(56^{\circ} \mathrm{C}\right)$ horse serum, $100 \mathrm{U} / \mathrm{ml}$ penicillin, $100 \mu \mathrm{g} / \mathrm{ml}$ streptomycin, $1 \%$ non-essential amino acids, $5 \mu \mathrm{g} / \mathrm{ml}$ transferrin, $5 \mathrm{ng} / \mathrm{ml}$ selenium and $10 \mu \mathrm{g} / \mathrm{ml}$ insulin (Gibco, Invitrogen Corp., Cergy-Pontoise, France). The use of horse serum avoids oxidative deamination of spermidine and spermine by serum amine oxidase. MDL $72527\left[\mathrm{~N}^{1}, \mathrm{~N}^{4}\right.$-bis(2,3-butanedienyl)1,4-butaneamine dihydrochloride] was synthesized as described previously (18). $\mathrm{N}^{1}$-acetylspermidine was synthesized as described by Dredar et al (19). Stock solutions of the procyanidins $(50 \mathrm{mg} / \mathrm{ml})$ were prepared in dimethylsulfoxide (DMSO). Owing to the limited solubility of procyanidins in aqueous media, the highest concentration used was $50 \mu \mathrm{g} / \mathrm{ml}$ culture medium. The final concentration of DMSO in the culture medium was $0.1 \%$. Cells were exposed for different times to procyanidins and/or MDL 72527, starting $24 \mathrm{~h}$ after seeding. Culture media were replaced every $48 \mathrm{~h}$. Cell growth was stopped by addition of $50 \mu \mathrm{l} /$ well trichloroacetic acid $(50 \% \mathrm{v} / \mathrm{v})$, and cell proteins were determined by staining with Sulforhodamine B (20). The relationship between cell number (protein content/well) and absorbance at $490 \mathrm{~nm}$ is linear from 0 to 200,000 cells per well.

Cell cycle analysis. Cell cycle distribution was analysed by labeling cells with propidium iodide. Assays were carried out as described by Nicoletti et al (21). Briefly, $1 \times 10^{6}$ cells were seeded in culture dishes and harvested by trypsinisation (0.5\% trypsin in $2.6 \mathrm{mM}$ EDTA). For cell sorting SW620 cells were collected by centrifugation, and fixed in $1 \mathrm{ml}$ methanol:PBS (9:1 v/v). After washing twice in PBS, cells were re-suspended in $200 \mu \mathrm{l}$ PBS containing $0.25 \mathrm{mg} / \mathrm{ml}$ RNAse A and $0.1 \mathrm{mg} / \mathrm{ml}$ propidium iodide (Sigma-Aldrich, St. Quentin Fallavier, France). After incubation in the dark at $37^{\circ} \mathrm{C}$ for $30 \mathrm{~min}$, the fluorescence of 10,000 cells was analyzed using a FACScan flow cytometer and CellQuest software (Becton Dickinson, San Jose, CA, USA).

Hydrogen peroxide assay. Cells were treated for $24 \mathrm{~h}$ with procyanidins in the absence or presence of MDL 72527. Intracellular hydrogen peroxide was determined by a method analogous to that developed by Bass et al (22) but using incubations of $30 \mathrm{~min}$ at $37^{\circ} \mathrm{C}$ with 5,6-chloromethyl-2',7'dichlorodihydrofluorescein diacetate (Invitrogen, Eugene, OR, 


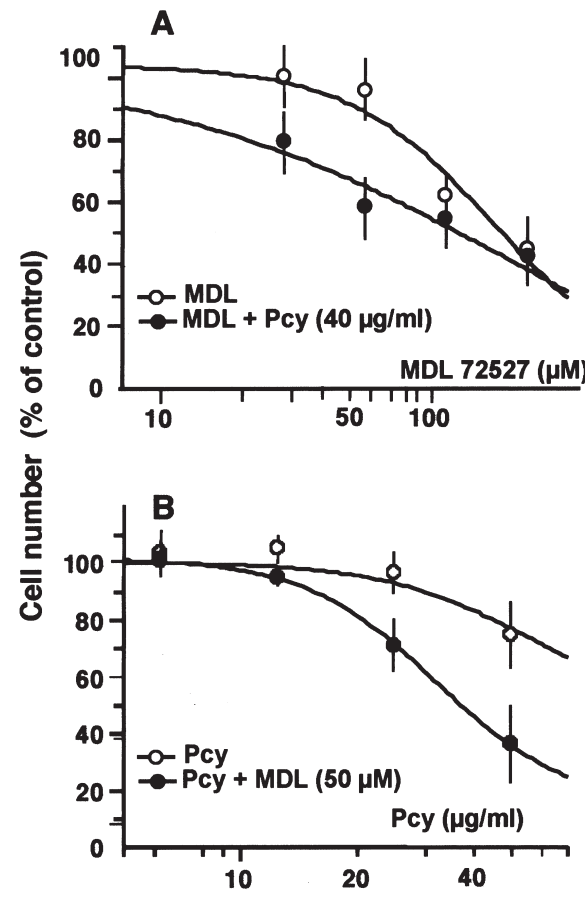

Figure 2. Inhibition of the growth of SW620 cells by MDL 72527 and procyanidins (Pcy). Dose response curves. Starting $24 \mathrm{~h}$ after seeding cells were exposed to MDL 72527, Pcy or both drugs for $48 \mathrm{~h}$, and cell protein in wells was determined. The error bars indicate \pm SE.

USA) as detector reagent. Cells were harvested by trypsinisation, and washed with PBS. Fluorescence resulting from the oxidation of the reagent was detected in 10,000 cells by flow cytometry. Samples incubated with hydrogen peroxide before trypsinisation served as positive controls.

$O D C$ and AdoMetDC assays. Cells were homogenized in $100 \mathrm{mM}$ Tris-HCl buffer, pH 7.4 (1 mM EDTA, $1 \mathrm{mM}$ dithiothreitol, $0.5 \mu \mathrm{M}$ leupeptin, $0.5 \mathrm{mM}$ phenylmethylsulfonyl fluoride). After centrifugation at $33,000 \mathrm{x}$ g for $25 \mathrm{~min}$ at $4^{\circ} \mathrm{C}$, the supernatants were collected and ODC and AdoMetDC assays were performed. ODC activity was evaluated by measuring ${ }^{14} \mathrm{CO}_{2}$ formation from $\left[1-{ }^{14} \mathrm{C}\right] \mathrm{L}$-ornithine $(55 \mathrm{mCi} /$ mmol, Amersham Pharmacia Biotech, Orsay, France) (23) and AdoMetDC by measuring ${ }^{14} \mathrm{CO}_{2}$ formed from $\left[1-{ }^{14} \mathrm{C}\right] \mathrm{S}$ adenosylmethionine $(60 \mathrm{mCi} / \mathrm{mmol}$, Amersham Pharmacia Biotech) (24).

Polyamine determinations. Cells were homogenized in perchloric acid $(200 \mathrm{mM})$, and the homogenates were centrifuged at $1500 \mathrm{x} \mathrm{g}$ for $10 \mathrm{~min}$ after standing for $16 \mathrm{~h}$ at $2^{\circ} \mathrm{C}$. The clear supernatants were diluted with perchloric acid (200 mM) and $200 \mu 1$ aliquots were applied on a reversed-phase column for separation. The polyamines and their $\mathrm{N}^{1}$-acetyl derivatives were determined by separation of the ion pairs formed with $\mathrm{n}$-octanesulfonic acid, reaction of the column effluent with ophthalaldehyde/2-mercaptoethanol reagent, and monitoring of fluorescence intensity (25).

Statistical analysis. All experiments were performed at least three times. If not stated otherwise, data are means \pm SE. Statistical differences between groups were evaluated by

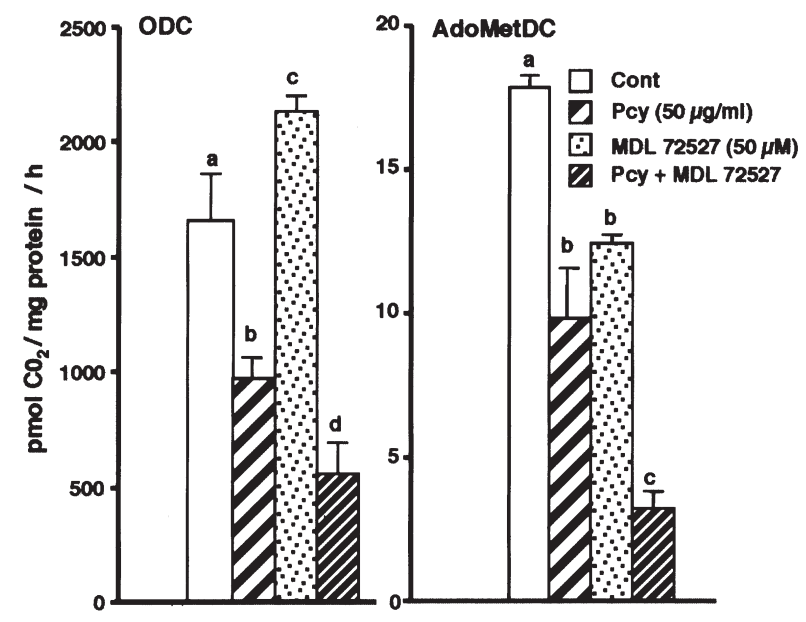

Figure 3. Effect of apple procyanidins (Pcy $50 \mu \mathrm{g} / \mathrm{ml}$ ) and MDL 72527 $(50 \mu \mathrm{M})$ on ODC and AdoMetDC cells after 24-h exposure to drugs. Results are means \pm SE. of three separate experiments. Columns not sharing the same superscript differ significantly $(\mathrm{p}<0.01)$.

one-way ANOVA and specific differences were identified using the Sudent's t-test or the Student-Neuman-Keuls multiple comparison test. Differences with $\mathrm{p} \leq 0.01$ are considered statistically significant.

\section{Results}

Cell growth inhibition by procyanidins and MDL 72527. Fig. 2A shows the dose-effect relationship of MDL 72527 on cell growth after 48-h exposure to the drug, at concentrations ranging from 30 to $125 \mu \mathrm{M}$. MDL 72527 reduced the growth rate only at doses exceeding $50 \mu \mathrm{M}$. Procyanidins $(40 \mu \mathrm{g} / \mathrm{ml})$ caused approximately $20 \%$ growth inhibition. At this concentration they enhanced significantly the antiproliferative effect of the PAO inactivator. As is shown in Fig. 2B, $50 \mu \mathrm{M}$ MDL 72527 potentiated the antiproliferative effect of the procyanidins; $60 \%$ growth inhibition was observed.

Alterations of polyamine metabolism. When SW620 cells were treated with procyanidins for $24 \mathrm{~h}$, the activities of ODC and AdoMetDC were reduced by 50\% (Fig. 3). MDL 72527 $(50 \mu \mathrm{M})$ did not affect ODC activity, but caused a significant decrease of AdoMetDC activity, and it enhanced the effect of procyanidins on ODC and AdoMetDC activities by $\sim 75 \%$.

Figs. 4 and 5 illustrate the effect of various treatments on the intracellular polyamine content, and on the formation of $\mathrm{N}^{1}$-acetyl polyamines. Cells treated with procyanidins alone exhibited a significant $(\mathrm{p}<0.01)$ decrease of spermine. This was accompanied by an increase of $\mathrm{N}^{1}$-acetylspermidine concentration, indicating the enhancement of polyamine catabolism. Obviously apple procyanidins exert a dual effect on polyamine metabolism by down-regulating polyamine biosynthesis and by stimulating polyamine catabolism.

Disregarding diamine oxidase-catalysed terminal catabolism of polyamines to amino acids two enzymes are mainly involved in polyamine catabolism: spermidine/spermine $\mathrm{N}^{1}$ acetyltransferase (SSAT) and PAO (26) (Fig. 1). Induction of SSAT was not accompanied by corresponding changes of PAO, which is usually expressed in excess. MDL 72527 


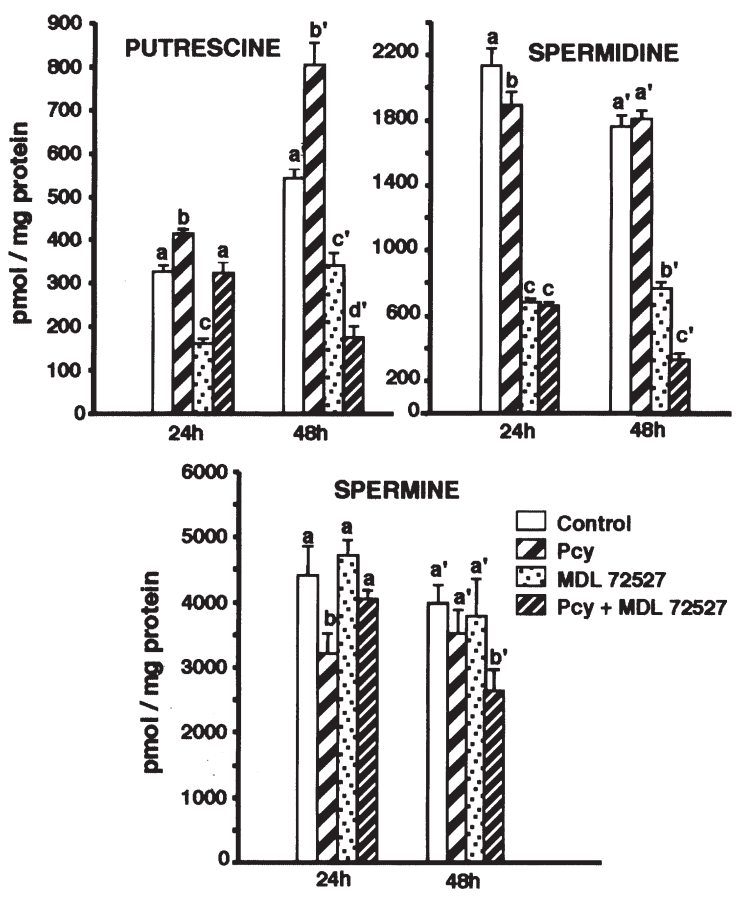

Figure 4. Effects of apple procyanidins (Pcy $50 \mu \mathrm{g} / \mathrm{ml}$ ) and MDL 72527 $(50 \mu \mathrm{M})$ on the polyamine content of SW620 cells. Cells were treated for 24 or $48 \mathrm{~h}$ with the compounds, harvested by scraping and extracted with $0.2 \mathrm{~N}$ perchloric acid. Results are means $\pm \mathrm{SE}$ of three separate experiments. Columns not sharing the same superscript differ significantly $(\mathrm{p}<0.01)$.

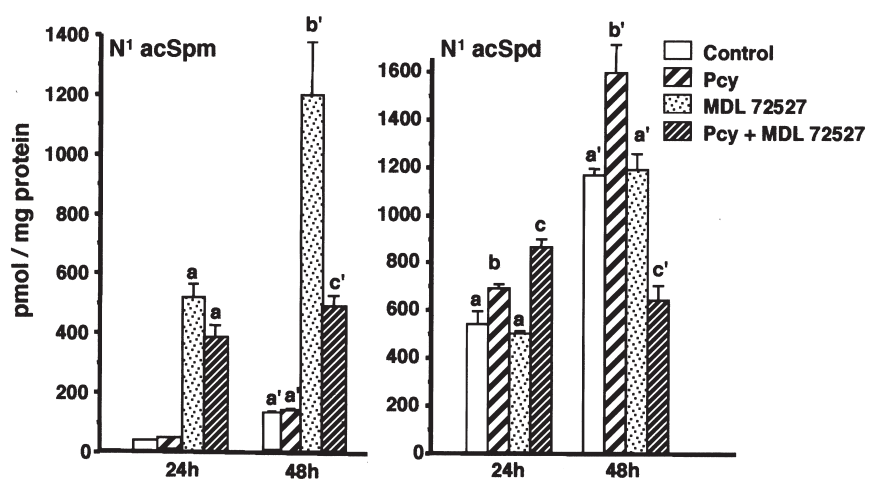

Figure 5. Effect of apple procyanidins (Pcy $50 \mu \mathrm{g} / \mathrm{ml}$ ) and MDL 72527 $(50 \mu \mathrm{M})$ on the formation of $\mathrm{N}^{1}$-acetylpolyamines. Cells were treated for 24 or $48 \mathrm{~h}$, harvested by scraping and extracted with $0.2 \mathrm{~N}$ perchloric acid. Results are the mean $\pm \mathrm{SE}$ of three separate experiments. Columns not sharing the same superscript differ significantly $(\mathrm{p}<0.01)$.

at $50 \mu \mathrm{M}$, a concentration that is sufficient to inactivate PAO completely (13) but, as was shown above, had no effect on SW620 cell growth, caused the accumulation of $\mathrm{N}^{1}$ acetylspermine and $\mathrm{N}^{1}$-acetylspermidine (Fig. 5). This increase in $\mathrm{N}^{1}$-acetyl derivatives is mainly due to prevention of PAO catalysed degradation, but the induction of SSAT can at present not be completely excluded, since MDL 72527 inhibits at concentrations $\geq 60 \mu \mathrm{M}$ the growth of SW620 cells (13). In combination with procyanidins, MDL 72527 diminished within $48 \mathrm{~h}$ the intracellular content of putrescine and spermidine pools, and reduced the amount of spermine more efficiently than procyanidins alone.

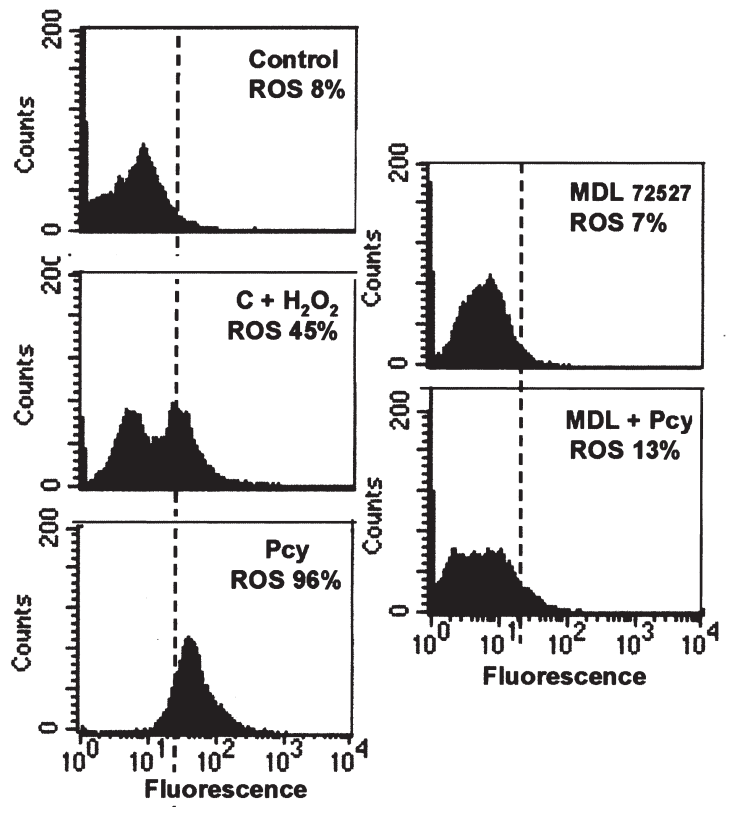

Figure 6. Generation of hydrogen peroxide in SW620 cells after treatment with apple procyanidins (Pcy $50 \mu \mathrm{g} / \mathrm{ml})$ and MDL $72527(50 \mu \mathrm{M})$. Cells were exposed to the drugs for $24 \mathrm{~h}$ and were collected by trypsinisation. After incubation for $30 \mathrm{~min}$ at $37^{\circ} \mathrm{C}$ with 5,6-chloromethyl-2',7'-dichlorodihydrofluorescein diacetate, oxidation of the reagent was detected by monitoring fluorescence using a FACScan flow cytometer. As a positive control hydrogen peroxide-treated samples were included.

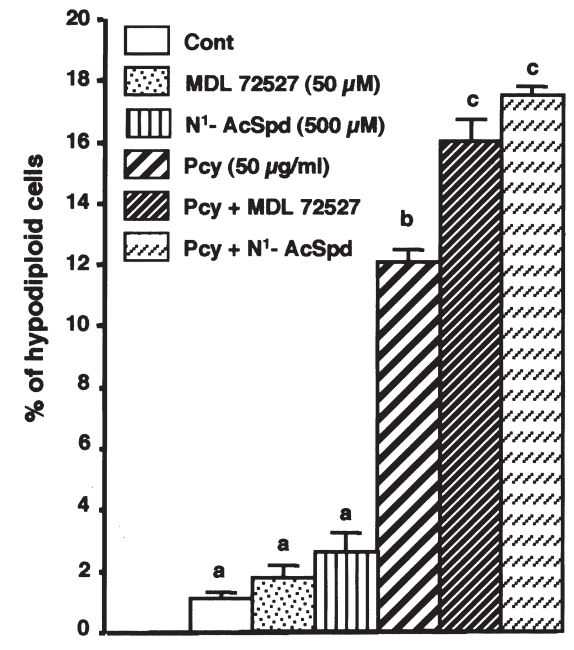

Figure 7. Percentage of hypodiploid cells after treatment with apple procyanidins (Pcy $50 \mu \mathrm{g} / \mathrm{ml}) \mathrm{MDL} 72527(50 \mu \mathrm{M})$ and $\mathrm{N}^{1}$-acetylspermidine $(500 \mu \mathrm{M})$. Cells were treated for $24 \mathrm{~h}$ with the various compounds. Hypodiploid cells were determined by flow cytometry. Results are means \pm $\mathrm{SE}$ of three separate experiments. Columns not sharing the same superscript differ significantly $(\mathrm{p}<0.01)$

Procyanidins and generation of reactive oxygen species $(R O S) . \mathrm{N}^{1}$-acetyl-polyamines serve as substrates of PAO, and generate hydrogen peroxide and 3-acetamidopropanal (27). Determination of intracellular hydrogen peroxide showed that procyanidins increase hydrogen peroxide accumulation (Fig. 6). When cells were incubated with the PAO inactivator and procyanidins, the formation of hydrogen peroxide was diminished by $80 \%$, indicating that ROS formation by 
procyanidins is at least to a considerable proportion directly due to the procyanidin-mediated activation of the polyamine catabolism.

Effect of MDL 72527 and $N^{1}$-acetylspermidine on procyanidinmediated cell death. Since ROS formation is known to be implicated in cell death $(10,28,29)$, we examined whether inhibition of ROS formation by MDL 72527 reduces cytotoxic effects triggered by procyanidins. MDL $72527(50 \mu \mathrm{M})$ alone had no significant effects on cell death. However, in combination with procyanidins $(50 \mu \mathrm{g} / \mathrm{ml})$, the PAO inactivator increased significantly $(\mathrm{p}<0.01)$ the proportion of hypodiploid (apoptotic) cells (Fig. 7). Since the enhancement of apoptosis by procyanidins and MDL 72527 was unrelated to the accumulation of hydrogen peroxide, we hypothesised that the intracellular accumulation of $\mathrm{N}^{1}$-acetyl-polyamines caused by MDL 72527 and procyanidins is somehow responsible for the observed effect. This idea is supported by the observation that $500 \mu \mathrm{M} \mathrm{N}^{1}$-acetylspermidine in the presence of procyanidins increased the proportion of apoptotic SW620 cells in a similar way to the exposure of cells to MDL 72527 plus procyanidins (Fig. 7). $\mathrm{N}^{1}$-acetylspermidine did not improve the apoptotic effect when added to MDL 72527/procyanidin combinations (not shown).

\section{Discussion}

Apple procyanidins diminish the formation of aberrant crypt foci in rat colon, trigger apoptosis, and alter signal transduction pathways in SW 620 cells (4). In order to study further the mechanistic basis of their chemopreventive effect, polyamine metabolism was studied as a potential target of procyanidins.

The diminution of cell growth rate is understandable on the basis that procyanidins reduce ODC and AdoMetDC activities, and decrease intracellular polyamine concentrations due to induction of SSAT. Inhibition of PKC activity by procyanidins contributes to these effects (4); since it is known that this enzyme is involved in the regulation of ODC (5). Its inhibition potentiates the antiproliferative effect of DL-2(difluoromethyl)ornithine, a selective inactivator of ODC (30). The observed changes in enzyme activities and polyamine pools resemble effects of known inducers of SSAT inasmuch as putrescine, spermidine and spermine concentrations were diminished, together with an increase of $\mathrm{N}^{1}$-acetylspermidine concentrations. However both, growth inhibition and polyamine pool changes, were considerably smaller than those usually reported for structural analogues of spermine (31), but resemble less potent SSAT inducers (example in ref. 32).

For inducers of SSAT it has repeatedly been shown that inactivation of PAO by MDL 72527 prevents apoptosis, because their apoptotic effect relies mainly on the PAO catalysed formation of hydrogen peroxide, and of 3acetamidopropanal from the excessively formed $\mathrm{N}^{1}$-acetyl derivatives of spermidine and spermine (33-35). The decrease in growth rate and the increased effects of treatments with procyanidins and MDL 72527 on SSAT, ODC, AdoMetDC and polyamine pools may not surprise, because they are in accordance with previous experience with SSAT inducers. However, it was surprising that MDL 72527 at an obviously non-toxic concentration improved growth inhibition and enhanced apoptosis in spite of the suppression of procyanidineinduced hydrogen peroxide formation. Since this effect of the PAO inactivator was mimicked by a high extracellular concentration of $\mathrm{N}^{1}$-acetylspermidine in the presence of procyanidins, a key role of hitherto unobserved properties of MDL 72527 on apoptosis can be excluded. Depletion of acetyl$\mathrm{CoA}$ due to the massive formation of $\mathrm{N}^{1}$-acetylpolyamines may contribute to growth inhibition in the case of highly potent inducers of SSAT (36), and one may speculate about the possibility that accumulation of intracellular N-acetylpolyamines affects histone acetylation by competing with acetylCoA:spermidine $\mathrm{N}^{8}$-acetyltransferase, an enzyme that has also histone acetylating properties (37). However, these and related effects are more likely to be observed in situations of excessive SSAT induction than under the conditions of the present work, although they cannot be excluded at present.

MDL 72527 is a lysosomotropic compound (38). Its cytotoxicity at elevated concentrations relies most probably on its lysosomotropic property, as is suggested from the excessive formation of vacuoles in SW620 cells (17). As a weaker base with a higher lipophilicity than spermidine, $\mathrm{N}^{1}$ acetylspermidine could also have hitherto unknown lysosomotropic properties. It seems not unlikely that the observed enhancement of procyanidin-triggered apoptosis by MDL 72527 and $\mathrm{N}^{1}$-acetylspermidine is due to the sensitisation of cells to lysosomotropic compounds by the procyanidins. This effect may be initiated by the known binding of procyanidins to the cell surface (3), which affects multiple signalling pathways (4) and may affect transmembrane transport.

Apple procyanidins are non-toxic, and are therefore highly promising new drugs, particularly in colon cancer chemoprevention. The potentiation of their apoptotic effect is, therefore, a challenging target for anti-cancer drug development.

\section{Acknowledgements}

This work was supported in part by the French Ministry of Research and Education, Grant Nutrialis no. 00P0621.

\section{References}

1. Perez-Ilzarbe FJ, Martinez V, Hernandez T and Estrella I: Liquid chromatographic determination of apple pulp procyanidins. J Liquid Chromatogr 15: 637-646, 1992.

2. Guyot S, Le Bourvellec C, Marnet N and Drilleau JF: Procyanidins are the most abundant polyphenols in dessert apples at maturity. Lebensm-Wiss u-Technol 35: 289-291, 2002.

3. Yang CS, Landau JM, Huang MT and Newmark HL: Inhibition of carcinogenesis by dietary polyphenolic compounds. Annu Rev Nutr 21: 381-406, 2001.

4. Gossé F, Guyot S, Roussi S, Lobstein A, Fischer B, Seiler N and Raul F: Chemopreventive properties of apple procyanidins on human colon cancer-derived metastatic SW620 cells and in a rat model of colon carcinogenesis. Carcinogenesis 26: 1291-1295, 2005.

5. Yamada S, Hirota K, Chida K and Kuroki T: Inhibition of phorbol ester-caused induction of ornithine decarboxylase and tumor promotion in mouse skin by staurosporine, a potent inhibitor of protein kinase C. Biochem Biophys Res Commun 157: 9-15, 1988.

6. Wheeler DL, Reddig PJ, Dreckschmidt NE, Leitges M and Verma AK: Protein kinase C delta-mediated signal to ornithine decarboxylase induction is independent of skin tumor suppression. Oncogene 21: 3620-3630, 2002.

7. Higuchi CM and Wang W: Comodulation of cellular polyamines and proliferation: biomarker application to colorectal mucosa. J Cell Biochem 57: 445-450, 1995. 
8. Pegg AE: Polyamine metabolism and its importance in neoplastic growth and a target for chemotherapy. Cancer Res 48: 759-774, 1988.

9. Seiler N: Thirty years of polyamine-related approaches to cancer therapy. Retrospect and prospect. Part 1. Selective enzyme inhibitors. Current Drug Targets 4: 537-564, 2003.

10. Schipper RG, Penning LC and Vershofstad AAJ: Involvement of polyamines in apoptosis. Facts and controversies: effectors or protectors? Semin Cancer Biol 10: 55-68, 2000.

11. Pignatti C, Tantini B, Stefanelli C and Flamigni F: Signal transduction pathways linking polyamines to apoptosis. Review article. Amino Acids 27: 359-365, 2004.

12. Seiler N and Raul F: Polyamines and apoptosis. J Cell Mol Med 9: 623-642, 2005

13. Seiler N, Duranton B and Raul F: The polyamine oxidase inactivator MDL 72527. Prog Drug Res 59: 1-40, 2003.

14. Souquet JM, Labarbe B, Le Guernevé C, Cheynier V and Moutounet M: Phenolic composition of grape stems. J Agr Food Chem 48: 1076-1080, 2000.

15. Guyot S, Marnet N and Drilleau JF: Direct thiolysis on crude apple materials for high-performance liquid chromatography characterization and quantification of polyphenols in cider apple tissues and juices. In: Methods in Enzymology - Flavonoids and Other Polyphenols. Parker L (ed). Vol. 335. Academic Press, New York, pp57-70, 2001

16. Duranton B, Holl V, Schneider Y, Carnesecchi S, Gossé F, Raul F and Seiler N: Polyamine metabolism in primary human colon adenocarcinoma cells (SW 480) and their lymph node metastatic derivatives (SW 620). Amino Acids 24: 63-72, 2003.

17. Duranton B, Holl V, Schneider Y, Carnesecchi S, Gossé F, Raul F and Seiler N: Cytotoxic effects of the polyamine oxidase inactivator MDL 72527 on two human colon carcinoma cell lines SW 480 and SW 620. Cell Biol Toxicol 18: 381-396, 2002.

18. Bey P, Bolkenius FN, Seiler N and Casara P: N-2,3-Butadienyl1,4-butanediamine derivatives. Potent irreversible inactivators of mammalian polyamine oxidase. J Med Chem 28: 1-2, 1985.

19. Dredar SA, Blankenship JW, Marchant PE, Manneh V and Fries DS: Design and synthesis of inhibitors of N8-acetyl spermidine deacetylase. J Med Chem 32: 984-989, 1989.

20. Skehan P, Storeng R, Scudero D, Monks A, McMahon J, Vistca D, Warran JT, Bokesch H, Kennedy S and Boyd MR: New colorimetric cytotoxicity assay for anticancer drug screening. J Natl Cancer Inst 83: 1107-1112, 1990.

21. Nicoletti I, Migliorati G, Pagliacci MC, Grignani F and Riccardi C: A rapid and simple method for measuring thymocyte apoptosis by propidium iodide staining and flow cytometry. J Immunol Methods 139: 271-279, 1991.

22. Bass DA, Parce W, Dechatelet LR, Szejda P, Seeds MS and Thomas M: Flow cytometry studies of oxidative product formation by neutrophils: a graded response to membrane stimulation. J Immunol 130: 1919-1927, 1983.

23. Richman RA, Underwood LE, Van JJW and Boina JJ: Synergic effect of cortisol and growth hormone on hepatic ornithine decarboxylase activity. Proc Soc Exp Biol Med 138: 880-884, 1971.
24. Persson L, Holm I and Heby O: Translational regulation of ornithine decarboxylase by polyamines. FEBS Lett 295: 175-178, 1986.

25. Seiler N and Knödgen B: High performance liquid chromatographic procedure for the simultaneous determination of the natural polyamines and their monoacetyl derivatives. J Chromatogr 221: $227-235,1980$

26. Seiler N: Catabolism of polyamines. Amino Acids 26: 217-233, 2004.

27. Bolkenius FN and Seiler N: Acetyl derivatives as intermediates in polyamine catabolism. Int J Biochem 13: 287-292, 1981.

28. Agostinelli E, Arancia G, Dalla Vedova L, Belli F, Marra M, Salvi M and Toninello A: The biological functions of polyamine oxidation products by amine oxidases: perspectives of clinical applications. Amino Acids 27: 347-358, 2004.

29. Dröge W: Free radicals in the physiological control of cell function. Physiol Rev 82: 47-95, 2002.

30. Khan NA, Havouis R, Quemener V and Moulinoux JP: Protein kinase $\mathrm{C}$ inhibitor (H-7) potentiates antiproliferative effects of a polyamine biosynthesis inhibitor. Anticancer Res 12: 1223-1226, 1992.

31. Bergeron RJ, McManis JS, Liu CZ, Feng Y, Weimar WR, Luchetta GR, Wu Q, Ortiz-Ocasio J, Vinson JR, Kramer D and Porter CW: Antiproliferative properties of polyamine analogues: a structure-activity study. J Med Chem 37: 3464-3476, 1994.

32. Porter CW, Cavanaugh PF Jr, Stolowich N, Ganis B, Kelly E and Bergeron RJ: Biological properties of $\mathrm{N}^{4}$ - and $\mathrm{N}^{1}, \mathrm{~N}^{8}-$ spermidine derivatives in cultured L1210 leukemia cells. Cancer Res 45: 2050-2057, 1985

33. Ha HC, Woster PM, Yager JD and Casero RA Jr: The role of polyamine catabolism in polyamine analogue-induced programmed cell death. Proc Natl Acad Sci USA 94: 11557-11562, 1997.

34. Ignatenko NA and Gerner EW: Growth arrest- and polyaminedependent expression of spermidine/spermine $\mathrm{N}^{1}$-acetyltransferase in human tumor cells. Cell Growth Diff 7: 481-486, 1996.

35. Chen Y, Kramer D, Jell J, Vujcic S and Porter CW: SiRNA suppression of polyamine analogue-induced spermidine/spermine $\mathrm{N}^{1}$-acetyltransferase. Mol Pharmacol 64: 1153-1159, 2003.

36. Kee K, Vujcic S, Merali S, Diegelman P, Kisiel N, Powell CT, Kramer D and Porter CW: Metabolic and antiproliferative consequences of activated polyamine catabolism in LNCaP prostate carcinoma cells. J Biol Chem 279: 27050-27058, 2004.

37. Desidero MA, Weibel M and Mamont P: Spermidine nuclear acetylation in rat hepatocytes and in logarithmically growing rat hepatoma cells: comparison with histone acetylation. Exp Cell Res 202: 501-506, 1992.

38. Dai H, Kramer DL, Yanag C, Murti KG, Porter CW and Cleveland JL: The polyamine oxidase inhibitor MDL 72527 selectively induces apoptosis of transformed hematopoietic cells through lysomotropic effects. Cancer Res 59: 4944-49454, 1999. 